\title{
Role of NKT Cells during Viral Infection and the Development of NKT Cell-Based Nanovaccines
}

\author{
Masood Alam Khan *(D) and Arif Khan (D) \\ Department of Basic Health Sciences, College of Applied Medical Sciences, Qassim University, \\ Buraydah 51452, Saudi Arabia; 4140@qu.edu.sa \\ * Correspondence: a_khan@qu.edu.sa; Tel.: +966-507059437; Fax: +966-63801628
}

Citation: Khan, M.A.; Khan, A. Role of NKT Cells during Viral Infection and the Development of NKT Cell-Based Nanovaccines. Vaccines 2021, 9, 949. https://doi.org/ 10.3390 /vaccines 9090949

Academic Editor: Hidehiro Fukuyama

Received: 9 August 2021

Accepted: 23 August 2021

Published: 26 August 2021

Publisher's Note: MDPI stays neutral with regard to jurisdictional claims in published maps and institutional affiliations.

Copyright: (C) 2021 by the authors. Licensee MDPI, Basel, Switzerland. This article is an open access article distributed under the terms and conditions of the Creative Commons Attribution (CC BY) license (https:// creativecommons.org/licenses/by/ $4.0 /)$.

\begin{abstract}
Natural killer T (NKT) cells, a small population of T cells, are capable of influencing a wide range of the immune cells, including $\mathrm{T}$ cells, $\mathrm{B}$ cells, dendritic cells and macrophages. In the present review, the antiviral role of the NKT cells and the strategies of viruses to evade the functioning of NKT cell have been illustrated. The nanoparticle-based formulations have superior immunoadjuvant potential by facilitating the efficient antigen processing and presentation that favorably elicits the antigen-specific immune response. Finally, the immunoadjuvant potential of the NKT cell ligand was explored in the development of antiviral vaccines. The use of an NKT cell-activating nanoparticlebased vaccine delivery system was supported in order to avoid the NKT cell anergy. The results from the animal and preclinical studies demonstrated that nanoparticle-incorporated NKT cell ligands may have potential implications as an immunoadjuvant in the formulation of an effective antiviral vaccine that is capable of eliciting the antigen-specific activation of the cell-mediated and humoral immune responses.
\end{abstract}

Keywords: NKT cells; vaccine; lipid ligands; immunoadjuvant; nanoparticles

\section{Introduction}

Natural Killer T (NKT) cells belong to a subset of T cells that can influence the status of the innate and adaptive immune systems because they secrete huge amounts of Th1 and Th2 cytokines (Figure 1) [1]. Earlier, the NKT cells were characterized by the NK and $\mathrm{T}$ cell properties as they express the natural killer (NK) cell lineage markers (NK1.1 or DX5 in mice and CD161 in human) and $\alpha \beta$ T-cell receptor (TCR) [1,2]. NKT cells are more appropriately defined as "CD1d-restricted and TCR- $\alpha \beta$ positive T cells". In mice, the NKT cells constitute about $0.2-2.0 \%$ of lymphocytes in the blood, spleen, bone marrow and thymus, and about $15-35 \%$ of total lymphocytes in the liver. On the other hand, the levels of NKT cells are lower in humans, comprising about $0.04-1.3 \%$ of circulating lymphocytes in the blood, spleen and bone marrow. They make up about $0.001-0.01 \%$ of lymphocytes in the thymus and about $1 \%$ in the liver [3]. The greater part of the NKT cells, called canonical or invariant NKT cells (iNKT cells) or type I NKT cells have a specific TCR $\alpha$-chain rearrangement (V $\alpha 14-\mathrm{J} \alpha 18$ in mice; $\mathrm{V} \alpha 24-\mathrm{J} \alpha 18$ in humans), associated with limited diverse V $\beta$ chains (Figure 2). Type II NKT cells, also called non-classical NKT cells, are more diverse in TCR $\alpha$-chain (but some $\mathrm{V} \alpha 3.2-\mathrm{J} \alpha 9, \mathrm{~V} \alpha 8$ in mice) and TCR- $\beta$ chains (but some V $\beta 8.2$ in mice) (Figure 2).

NKT cells have the ability to recognize lipid or glycolipid antigens that are presented by the non-classical Major histocompatibility complex (MHC) I-like CD1 molecule [1]. The professional antigen-presenting cells (APCs), including macrophages, B cells and dendritic cells express the CD1 molecules. The CD1 family consists of two groups: group 1 CD1 includes CD1a, CD1b, and CD1c, whereas CD1d is the only member of CD1 group 2. There are two CD1d molecules (CD1d1 and CD1d2) in mice. CD1d molecules bind to their specific ligands that activate the NKT cells [1]. Contrary to type I and II NKT cells, the NKT-like cells are $\mathrm{CD}^{+} \mathrm{CD}^{+} 6^{+}$and are independent of CD1d (Figure 2) [4]. The NKT-like 
cells express the diverse TCR- $\alpha$ and TCR- $\beta$ chains. They are nonreactive to $\alpha$-Galcer and secrete Th1 cytokines. They are not detectable in newborns, whereas their numbers are increased in elderly individuals [4]. In a recent report, Terrazzano G. et al. defined CD3 ${ }^{+}$ $\mathrm{CD} 6^{+} \mathrm{T}$ cells as $\mathrm{T}_{\mathrm{R} 3-56}$ cells that play a regulatory role by controlling the effector function of $\mathrm{CD}^{+} \mathrm{T}$ cells. The frequency of $\mathrm{T}_{\mathrm{R} 3-56}$ cells was found to be reduced in type 1 diabetes [5].

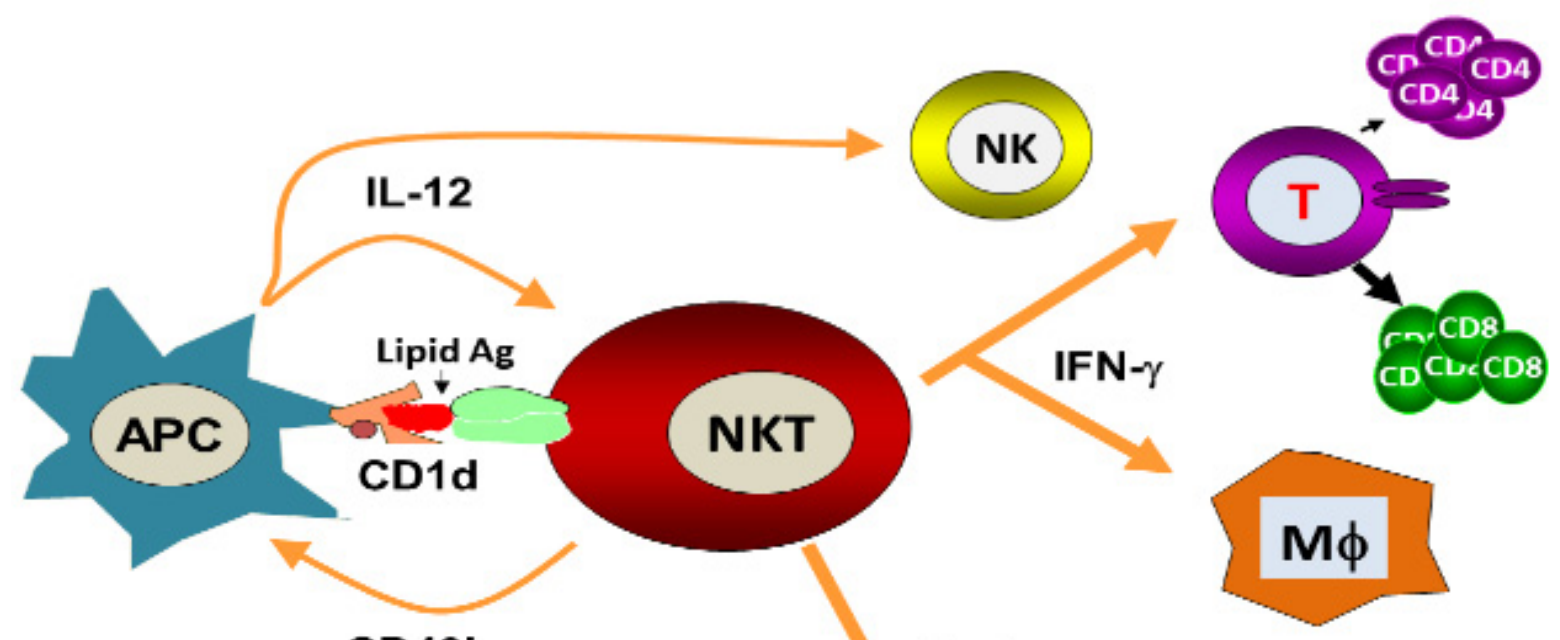

\section{CD40L}

IFN- $\gamma$

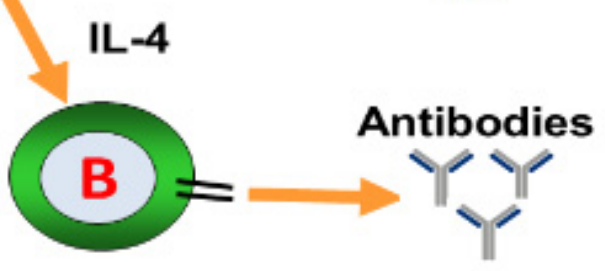

Figure 1. Activation of NKT cells results in the secretion of Th1 and Th2 cytokines. Lipid antigens presented by CD1d activate NKT cells, resulting in the secretion of IFN- $\gamma$ and IL-4. IFN- $\gamma$ activates the T cells and macrophages that are important players in cell-mediated immunity, whereas IL-4 acts on B cells and contributes to humoral immunity.

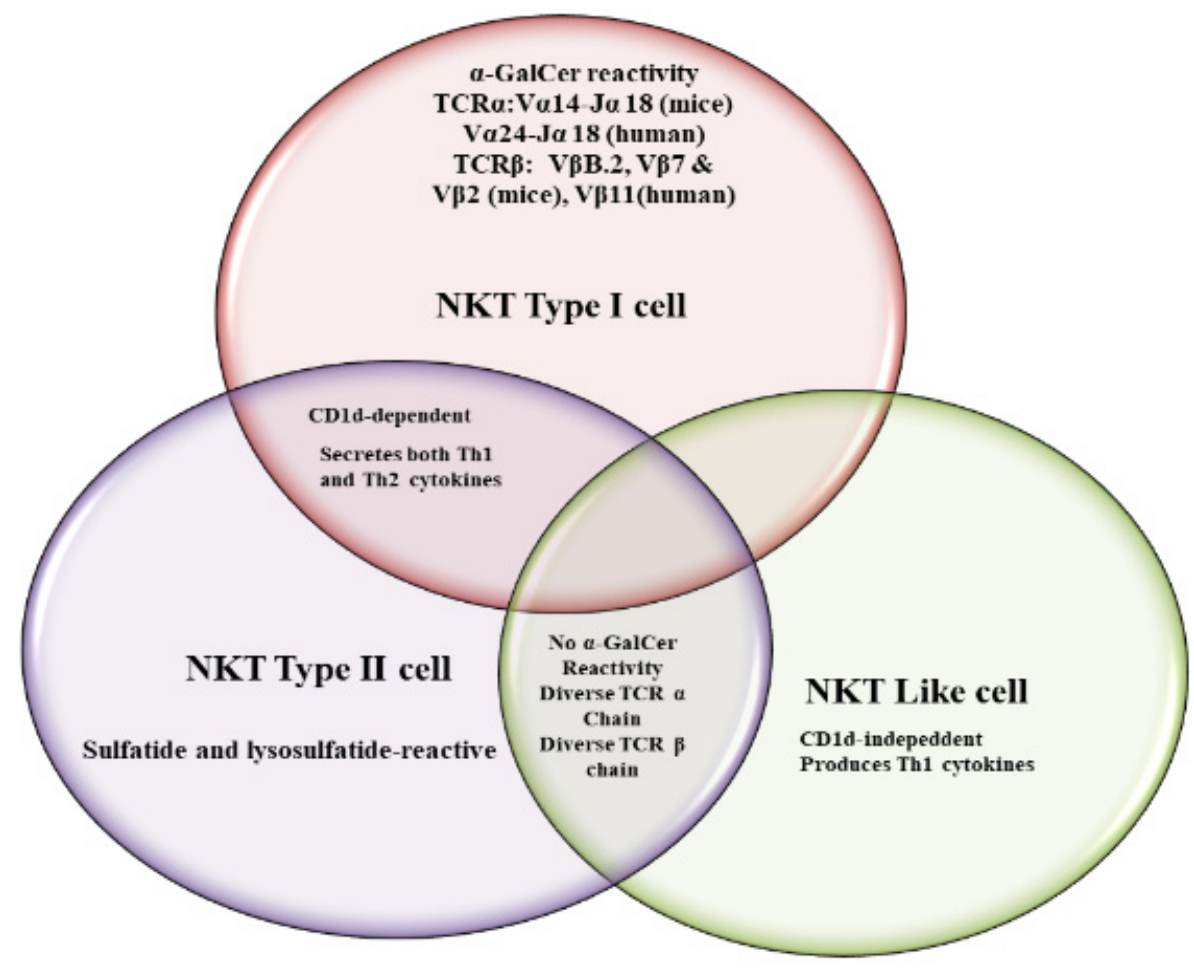

Figure 2. Similarities and differences between different types of NKT cells. 
Besides type I and type II NKT cells, other CD1d-restricted cells also express a semiinvariant $\mathrm{V} \alpha 10-\mathrm{J} \alpha 50 \mathrm{TCR}$ and are CD1d/ $\alpha$-GalCer tetramer-positive cells that have been demonstrated in $J \alpha 18^{-/-}$mice [6]. Mucosal-associated invariant T cells (MAIT Cells), a subset of T cells restricted to the MHC class I-related molecule (MR1-restricted T cells), are characterized by the expression of a semi-invariant TCR composed of a canonical TCR $\alpha$ chain (V $\alpha 19-\mathrm{J} \alpha 33$ in mice and $\mathrm{V} \alpha 7.2-\mathrm{J} \alpha 33$ in humans) associated with a restricted set of $\mathrm{V} \beta$ segments [7]. Several subsets of the human and mouse MAIT cells have recently been identified using diverse $\alpha \beta$ TCR. The MAIT cells can respond to TCR signals or to various activating cytokines, including IL-12, IL-1 $\beta$, IL-18, and IL-23 [8-10]. Upon activation, MAIT cells produce huge amounts of Th1- and Th17-related cytokines, such as IFN- $\gamma$, TNF- $\alpha$, IL-17A, and IL-22 [11]. Additionally, MAIT cells have the ability to kill bacteria-infected cells [12,13].

\section{NKT Cell Ligands}

NKT cells are activated by the specific exogenous or endogenous ligands presented by CD1d molecules. The most common exogenous CD1d ligand, $\alpha$-Galactosylceramide $(\alpha-\mathrm{GalCer})$, was originally extracted from a marine sponge Agelas mauritians [14]. Later on, $\alpha$-GalCer was also found to be secreted by the two human gut commensals, including Bacteroides vulgatus and Prevotella Capri $[15,16]$. Glycosphingolipids, from a lipopolysaccharide (LPS)-free bacteria Sphingomonas paucimobilis, activate the NKT cells in a CD1ddependent manner [17]. Some microbial components such as lipophosphoglycan from Leishmania donovani andasperamide B from Aspergillus fumigatus can stimulate type I NKT cells, whereas sulfatide, lysophosphatidylcholine, lyso-GL-1, phosphatidylglycerol (PG), di-phosphatidylglycerol (DPG), phosphatidylinositol (PI) from Corynebacterium glutamicum, PG and DPG from Listeria monocytogenes and DPG from Mycobacterium tuberculosis can activate type II NKT cells [18-20]. Upon activation with specific ligands, NKT cells secrete a copious amount of Th1 (IFN- $\gamma$, IL-2 and GM-CSF) and Th2 (IL-4, IL-10 and IL-13) cytokines that act on the cells of the innate and adaptive immunity [21,22].

NKT cells play a very important role against a wide range of pathogens, including viruses, protozoans, bacteria and fungi [23]. The NKT cell ligands have been suggested to be effective immunoadjuvants in the formulation of synthetic vaccines [24]. Taking their immune-stimulatory role into consideration, NKT cell ligands may be very useful in the preparation of vaccine formulation and immunotherapeutics in order to prevent infectious diseases. Since NKT cells have a role in the regulation of the innate and adaptive immune responses, the pathogens try to evade the functioning of NKT cells in order to establish the infection. In the present review, we describe the antiviral roles of NKT cells and also discuss the implications of NKT cell-based nanoparticle vaccines to protect against viral infections.

\section{Role of iNKT Cells against Viral Infections}

NKT cells have antiviral potential against hepatitis B virus (HBV), respiratory syncytial virus (RSV), encephalomyocarditis virus (EMCV), Herpes simplex virus-1 (HSV-1), coxsackievirus B (CVB), lymphocytic choriomeningitis virus (LCMV), influenza A virus (IAV) and murine cytomegalovirus (MCMV) [25-30]. They constitute an important arm of the innate immune response against viruses and can also regulate the adaptive immune responses by modulating the antigen-presenting cells (APCs). NKT cells exert the direct cytolytic effects and restrict the replication of viruses. Moreover, they can indirectly induce an antiviral state through the secretion of important cytokines. $\alpha$-GalCer-activated NKT cells reduced the replication of murine cytomegalovirus [30]. Likewise, $\alpha-G a l C e r$ administration protected the mice against viral encephalomyocarditis [27]. Wu et al. showed that $\alpha$-GalCer protected the mice against coxsackievirus B3 (CVB3)-induced myocarditis [31]. Johnson et al. demonstrated that NKT cell activation has been shown to induce the expansion of Cytotoxic T lymphocytes (CTLs) response and enhance the immune response against RSV [32]. The activation of the NKT cell resulted in the reduction of the viral load in the pancreas of LCMV-infected mice and this effect was mediated through the secretion of type I interferon [28]. Whereas, $\alpha$-GalCer-induced activation of NKT cells 
against HBV was shown to be mediated by IFN- $\alpha / \beta$ and IFN- $\gamma$ secretion [25]. However, the antiviral effect of NKT cells against the IAV is mediated through the activation of the innate immune responses [29]. Type I NKT cells exhibited a critical role against IAV infection by increasing IAV-specific CD8 ${ }^{+} \mathrm{T}$ cell response and viral clearance [33]. Singh et al. showed that cytokines produced by iNKT cells were associated with non-progressive HIV-I infection and patients had a lower viral load in their plasma [34]. There have been many studies that support the role of NKT cells against viral infections in humans. For example, some patients with mutated adaptor protein SAP (signaling lymphocyte activation molecule-associated protein) were found to be deficient in invariant iNKT cells [35]. These patients have been found to be susceptible to EBV infection. In an another study, patients mutated in the X-linked inhibitor of the apoptosis protein (XIAP) showed the selective reduction in iNKT cell numbers without affecting B cells, T cells and NK cells [36]. The Wiskott-Aldrich syndrome (WAS), a primary immune deficiency disease in humans, has been shown to be associated with an iNKT cell deficiency that impaired the functioning of the innate and adaptive immune systems and therefore predisposed the patients to viral infections [37]. The NKT cells play a very important role in linking the innate and adaptive immunity, their deficiency causes severe immunodeficiency in those persons for whom vaccination with attenuated pathogens is a serious challenge. This was evident from a report that a girl with impaired iNKT cell number and function developed severe respiratory distress after vaccination with the attenuated varicella-zoster virus (VZV) [38].

NKT cells have been actively involved in immune responses against HSV-1 and HSV-2 as NKT cell-deficient mice showed severe HSV-1 infection and impaired viral clearance [39]. The immune evasion strategy of HSV includes the inhibition of NKT cell recognition by curbing the CD1d recycling from the late endosomal compartments to the cell surface [40]. The protective role of NKT cells against RSV was evident from the fact that $\mathrm{Cd} 1 \mathrm{~d}^{-/-}$mice infected with RSV showed a poor ability to clear the viral load [39]. MCMV is considered a study model for human cytomegalovirus (HCMV). The iNKT cell activation by MCMV cells requires the involvement of IL-12 and type I interferon, but was independent of CD1d [41]. In an another study, a role of iNKT cells and CD1d has been suggested to counter the MCMV-induced suppression of hematopoiesis in mice [42]. The CD1d-dependent activation of NKT cells plays an important role in resisting EMCV infection because $\mathrm{Cd} 1 \mathrm{~d}^{-/-}$mice demonstrated more brutal paralysis due to an acute cytopathic effect of EMCV on neuronal cells [27]. The iNKT cells also played an important role in protecting against IAV because iNKT cell-deficient mice showed more severe bronchopneumonia. The adoptive transfer of iNKT cells before the infection reversed the effect of IAV-induced bronchopneumonia [43].

The NKT cells are found in the highest numbers in the livers of mice and therefore are supposed to play a very important role in understanding the pathology of liver diseases [44]. The activation of NKT cells had a protective role against HBV infection $[25,45]$. The absence of NKT cells or CD1d in mice resulted in diminished HBV-specific T and B cell responses with delayed viral clearance [46]. Toll-like receptor (TLR) ligands have been shown to activate iNKT cells [47]. Viruses altered the antigen presentation by CD1d through the activation of pattern recognition receptors, such as TLRs. The endosomal TLRs (TLR 3, 7, 8, and 9) are involved in detecting viruses by recognizing the nucleic acid structures [48]. TLRmediated recognition of viruses may lead to altered CD1d-mediated antigen presentation, thereby affecting the activation of iNKT cells. The role of NKT cells has been extensively reported against viral infections in pigs. The percentage of iNKT cells were increased in the blood, lymph node and broncho-alveolar lavage of pigs upon IAV infection [49]. Renukaradhya et al. demonstrated the role of iNKT cells in the regulation of airway hyperreactivity [50]. The intranasal administration of NKT cell ligand ameliorated H1N1 IAV infection in piglets [51], while the adjuvant effect of $\alpha$-GalCer potentiated the immune response of the inactivated HIN1 influenza virus in pigs [52]. 


\section{Evasion of the NKT Cell Functioning by Viruses}

Microbial pathogens can cause recurrent or persistent infections by avoiding the onslaught of the normal host immunity. Viruses adopt different strategies to evade both the innate and adaptive arms of the immune system (Figure 3). For example, HIV weakens the immune system by depleting the numbers of $\mathrm{CD}^{+} \mathrm{T}$ cells [53]. Some viruses, such as the herpes virus and Epstein-Barr virus (EBV), have the ability to enter into a latent state. Although the viruses do not replicate in the latent state, they cannot, however, be eliminated and can reactivate themselves to a fully virulent form. Invariant NKT (iNKT) cells have shown an antiviral immunity upon stimulation with $\alpha$-GalCer against HIV, MCMV, RSV, HBV and influenza virus infections [25-30,54]. There has been a reported reduction in the iNKT cell numbers in $\mathrm{HIV}-1^{+}$patients, particularly a depletion in the $\mathrm{CD} 4^{+}$ iNKT cell subset [55]. Moreover, HIV also causes the functional impairment of iNKT cells as the $\mathrm{CD}^{+}{ }^{+}$and $\mathrm{CD} 4^{-}$iNKT cells secrete a lower amount of IFN- $\gamma$, TNF- $\alpha$, and IL-4 in response to $\alpha$-GalCer/IL-2/PMA stimulation [56]. Viruses have adopted many tactics to avoid the assault by the immune system. For example, HIV-1 reduces the expression of CD1d molecules by increasing its internalization and retains them in the trans-Golgi network. The downregulation in the cell surface CD1d is caused by the interaction of CD1d intra-cytoplasmic tyrosine with HIV-1 Nef protein [57,58]. The CD4 ${ }^{+}$NKT cells showed greater susceptibility, as compared to conventional $\mathrm{CD} 4^{+} \mathrm{T}$ cells, to HIV-1 infection owing to the elevated level of CCR5 coreceptor expression on iNKT cells [59]. Fernandez et al. demonstrated an early NKT cell depletion in HIV-infected individuals [60]. Besides, iNKT cells showed their functional impairment as they produced lower levels of Th1 and Th2 cytokines in response to $\alpha$-GalCer [61]. The functional status of NKT cells is significantly preserved in the long term nonprogressors (LTNPs) as compared to the progressors [34].

Cell signaling pathways play an important role in modulating the CD1d-mediated antigen presentation to NKT cells by viruses [62]. We have earlier shown that vaccinia virus (VV) evaded the NKT cell activity by inhibiting the CD1d-mediated antigen presentation through the alteration of the mitogen-activated protein kinases (MAPKs) (Figure 3) [63]. A VV infection inhibited the CD1d-mediated antigen presentation by activating the p38 MAPK. The inhibition of p38 MAPK signaling using a specific inhibitor SB203580 rescued the VV-induced inhibition of CD1d-mediated antigen presentation. The alteration of MAPKs activation changed the intracellular trafficking of CD1d through the ligand-loading endocytic compartments [63]. In another study, we demonstrated that JNK2 negatively regulated the antigen presentation by CD1d and also contributed to the IL-12 induced activation of iNKT cells [64].

The signal transducer and activator of transcription-3 (STAT-3) has been shown to activate NKT cells by promoting CD1d-mediated antigen presentation [65]. The STAT-3 signaling induces an antiviral immunity as the treatment with a specific STAT-3 inhibitor increased the viral load in VV-infected mice [66]. In an another study, we and colleagues showed that a vesicular stomatitis virus (VSV) inhibited the CD1d-mediated antigen presentation much faster as compared to that inhibited by VV. A matrix protein, M protein, of VSV played a key role in inhibiting CD1d-mediated antigen presentation [67]. Moreover, a chronic LCMV infection caused a long-term loss of NKT cells in mice [68,69]. Interestingly, the acute infection of mice with LCMV caused a reduction in CD1d cell surface expression on dendritic cells and macrophages [68]. Moreover, West Nile virus (WNV) interferes with the interaction of dendritic cells (DCs) with NKT cells and thus inhibits the secretion of proinflammatory cytokines [70]. Kovats et al. showed that WNV-infected human dendritic cells failed to fully activate NKT cells [70]. HSV-1 has been shown to inhibit CD1d-mediated antigen presentation by suppressing the recycling of CD1d on the cell surface [71]. Viral glycoprotein protein $(\mathrm{gB})$ and viral serine-threonine kinase US3 are required to inhibit the CD1d antigen presentation and NKT cell activation. 


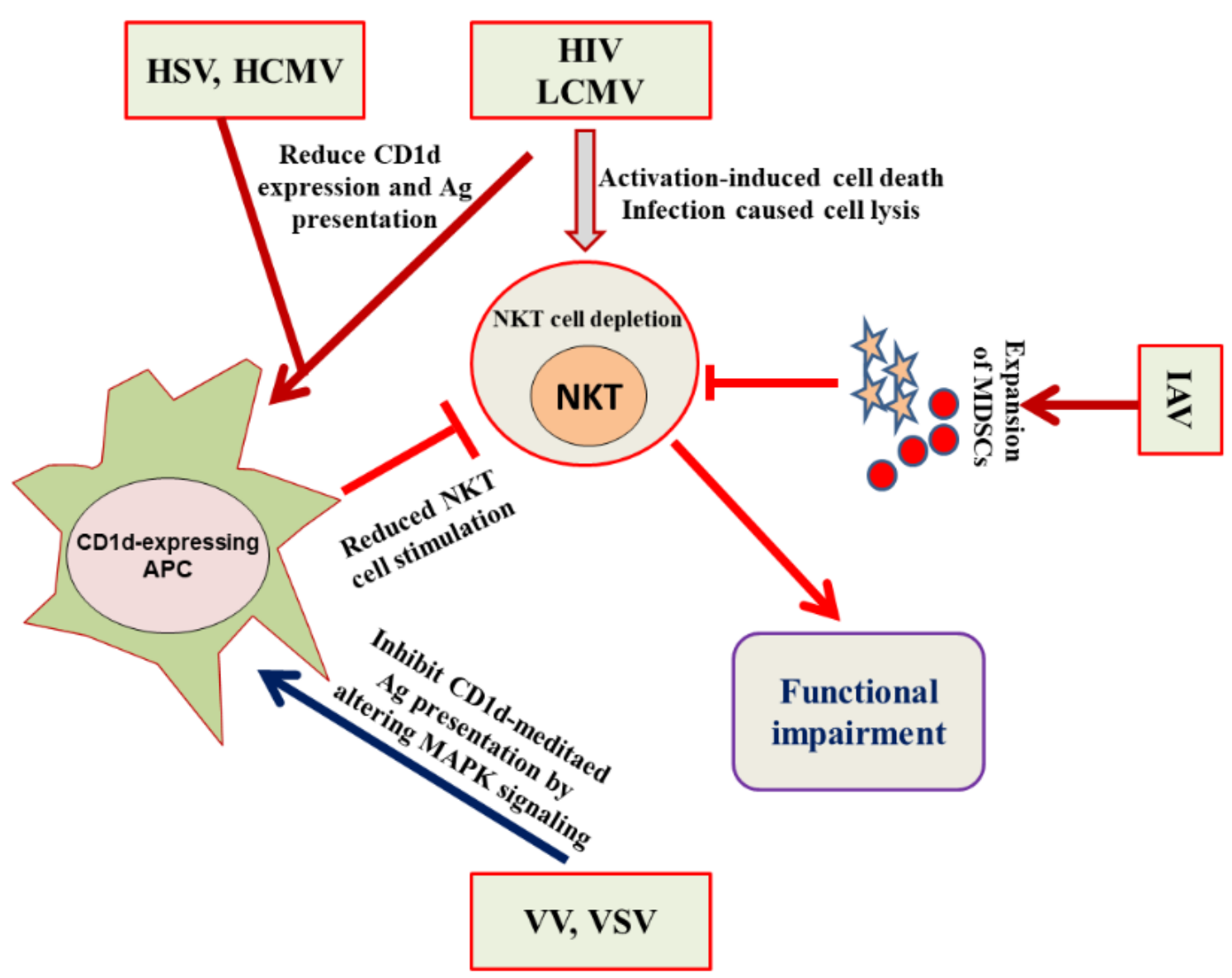

Figure 3. HIV, LCMV, HSV, HCMV, VV, VSV and IAV adopt different strategies to evade the NKT cell-mediated immune responses. HSV, HCMV, HIV and LCMV reduce the expression of CD1d on APCs. HIV and LCMV induce the activationinduced cell death in NKT cells. IAV induces the expansion of MDSCs that cause the impairment of NKT cell functioning. VV and VSV impede the NKT cell stimulation by inhibiting the CD1d-mediated antigen presentation.

Programmed death (PD)-1 is a member of the CD28 family of the costimulatory molecules and its interaction with its ligands PD-L1 and PD-L2 on APC sends the inhibitory signals to T cells [72]. The PD-1:PD-L interaction contributes to the induction of NKT cell anergy [73]. It has been shown that an increased expression of PD-1 on the T cells in HIV-1 infection induces $\mathrm{T}$ cell exhaustion and contributes to the progression of the disease [74]. Moll et al. demonstrated the elevated expression of PD-1 and functional impairment in CD1d-restricted NKT cells in the chronic infection of HIV-1 [56]. The coadministration of anti-PDL1 monoclonal antibody and $\alpha$-GalCer modulated the NKT cell activity and inhibited HBV infection [44]. Recently, Zingaropoli et al. showed a reduction in NKT cells in the peripheral blood of COVID-19 patients [75].

\section{Nanotechnology-Based Vaccine Delivery Platforms and the Development of an NKT Cell-Based Nanovaccine}

The development of nanotechnology-based formulations has shown great promise for the development of new generation vaccines. The nanoparticle-based delivery systems not only improve the stability of the vaccine, but also increase the immunogenicity of the encapsulated antigens by delivering them to the intracellular locations of APCs. The shape, size and the surface properties of the delivery systems determine their efficacy as an immunoadjuvant. Various types of vaccine delivery systems, including gold and silver nanoparticles, liposomes and chitosan nanoparticles have the ability to induce the antigenspecific $\mathrm{T}$ cell responses and antibody responses [76]. The important vaccine nanocarriers 
include liposomes, inorganic nanoparticles, chitosan nanoparticles, PLGA nanoparticles and virus-like particles (VLPs) [77,78].

\subsection{Inorganic Nanoparticles}

Several inorganic nanoparticles, including gold, silver, silica and iron have been formulated as vaccine delivery systems [79]. Influenza virus M2 membrane protein immobilized on gold-nanoparticles induced protective immunity against influenza A subtypes [80]. Silica nanoparticles loaded with CV2-ORF2 proteins elicited antigen-specific cell- and antibody-mediated immune responses [81]. Carbon nanotube-conjugated peptides from the foot-and-mouth disease virus elicited a strong antigen-specific immune response [82].

\subsection{Liposomes}

Liposomes are the unilamellar or multilamellar lipid vesicles that are composed of biodegradable phospholipids, including phosphatidylserine, phosphatidylcholine and cholesterol. Liposomes deliver the antigens to the cytoplasmic compartments by fusing with the membrane of the APCs [78]. The modification of the liposomal surface with certain molecules increases the immunoadjuvant potential of the liposomes [83,84]. Liposomes composed of cationic lipids elicited a strong immune response against the hepatitis $\mathrm{B}$ surface antigen (HBsAg) [85]. In addition, liposomes have been shown to be very effective in inducing antigen-specific immune responses against IAV and RSV [86,87].

\subsection{Polymeric Nanoparticles}

The polymer-based vaccine carriers are composed of biodegradable polymers, including chitosan, polylactic acid, polyglutamic acid, and poly(lactic-glycolic acid) [88]. Among them, the chitosan-based nanoparticle vaccine carriers have been extensively studied due to their biodegradability and reduced toxicity [89]. Chitosan-bearing nanoparticles have been shown to improve the immunogenicity of the influenza virus vaccine [90]. The design of poly(lactic-co-glycolic acid) (PLGA) nanoparticles improved the antigen-specific immune responses [91] Moreover, PLGA nanoparticles increased the antigen-specific lymphocyte proliferation against H1N2 antigens [92].

A successful vaccine should be able to induce a strong $\mathrm{CD} 8^{+} \mathrm{T}$ cell immune response in order to protect against viral infections (Figure 4). Generally, the vaccines composed of the live attenuated pathogens can generate $\mathrm{CD} 8^{+} \mathrm{T}$-cell-mediated immune responses $[93,94]$. The antiviral activity of the NKT cells is evident from the fact that NKT-cell-deficient mice showed a greater susceptibility to viruses $[95,96]$. Since NKT cells have a unique ability to stimulate the innate and adaptive immune responses, the NKT-cell ligand may prove to be an effective immunoadjuvant in the development of a successful vaccine.

The NKT cells show immune-stimulating activity through the maturation of the dendritic cells and boosting of antibody production $[97,98]$. Since they induce a rapid maturation of the dendritic cells (DCs) and B cells, their activation may elicit a strong antigen-specific immune responses. Various studies have shown the immunoadjuvant effect of $\alpha$-GalCer in protection against influenza virus infections $[99,100]$. The use of a synthetic glycolipid ABX196, an NKT ligand, demonstrated an immunoadjuvant effect and stimulated an anti-HB antibody response in human volunteers [101]. Huang et al. reported that $\alpha$-GalCer enhanced the immunogenicity of the DNA vaccine by increasing antigen-specific T-cell and antibody immune responses [102]. A major drawback with the use of $\alpha$-GalCer is that its sequential systemic administration results in the NKT cell anergy that hampers the development of the NKT-based immunotherapeutics (Figure 5). Moreover, the presentation of $\alpha$-GalCer by the nonprofessional APCs may induce NKT cell anergy. In order to exploit the NKT cell-mediated immune stimulation, it is important to codeliver the NKT cell ligand and antigens to the professional APCs such as dendritic cells. The co-administration of $\alpha$-GalCer and soluble antigens enhanced the antigen-specific cell-mediated and humoral immunity [103]. However, the coadministration of $\alpha$-GalCer and soluble antigens does not necessarily ensure that they are taken up by the same APC. 
In order to fully exploit the iNKT role to induce an effective CD8 ${ }^{+} \mathrm{T}$-cell response, it is essential that $\alpha-\mathrm{GalCer}$ and antigens are delivered to the same professional APC. This goal can be achieved by using the nanoparticles as delivery systems for antigens and NKT cell ligand. The liposome-mediated delivery of $\alpha$-GalCer and tumor-associated antigens (TAA) has resulted in an increased antigen-specific $\mathrm{CD}^{+} \mathrm{T}$-cell response [104]. Another study showed that the delivery of $\alpha$-GalCer with ovalbumin (OVA) in poly(lactic-co-glycolic acid) (PLGA) nanoparticles induced a very strong antigen-specific CD8 ${ }^{+} \mathrm{T}-$-cell response [105].

We have earlier shown that liposomes can fuse with the membrane of APC and deliver the antigens to the cytoplasmic compartment for processing [74]. These antigens are presented by MHC class I molecules to induce the activation of $\mathrm{CD} 8^{+} \mathrm{T}$ cells. The activation of antigen-specific CTLs is critical in the development of an antiviral vaccine. Moreover, the liposome-encapsulated antigens are also taken by the APCs through phagocytosis where the antigens are presented by MHC class II molecules to $\mathrm{CD} 4^{+} \mathrm{T}$ cells resulting in the secretion of various cytokines. On the other hand, MHC class I-like CD1d molecules present glycolipid antigens to NKT cells. The iNKT cell-specific ligands recruit NKT cells, like CD4 ${ }^{+}$ $\mathrm{T}$ cells, that play an important role in the modulation of the humoral and cytotoxic T-cell responses. The stimulation of NKT cells leads to the activation of downstream immune cells, including NK cells, DCs, macrophages, B cells, and conventional T cells. Many of these immune cells secrete immune-modulating cytokines, creating an entire activation cascade.

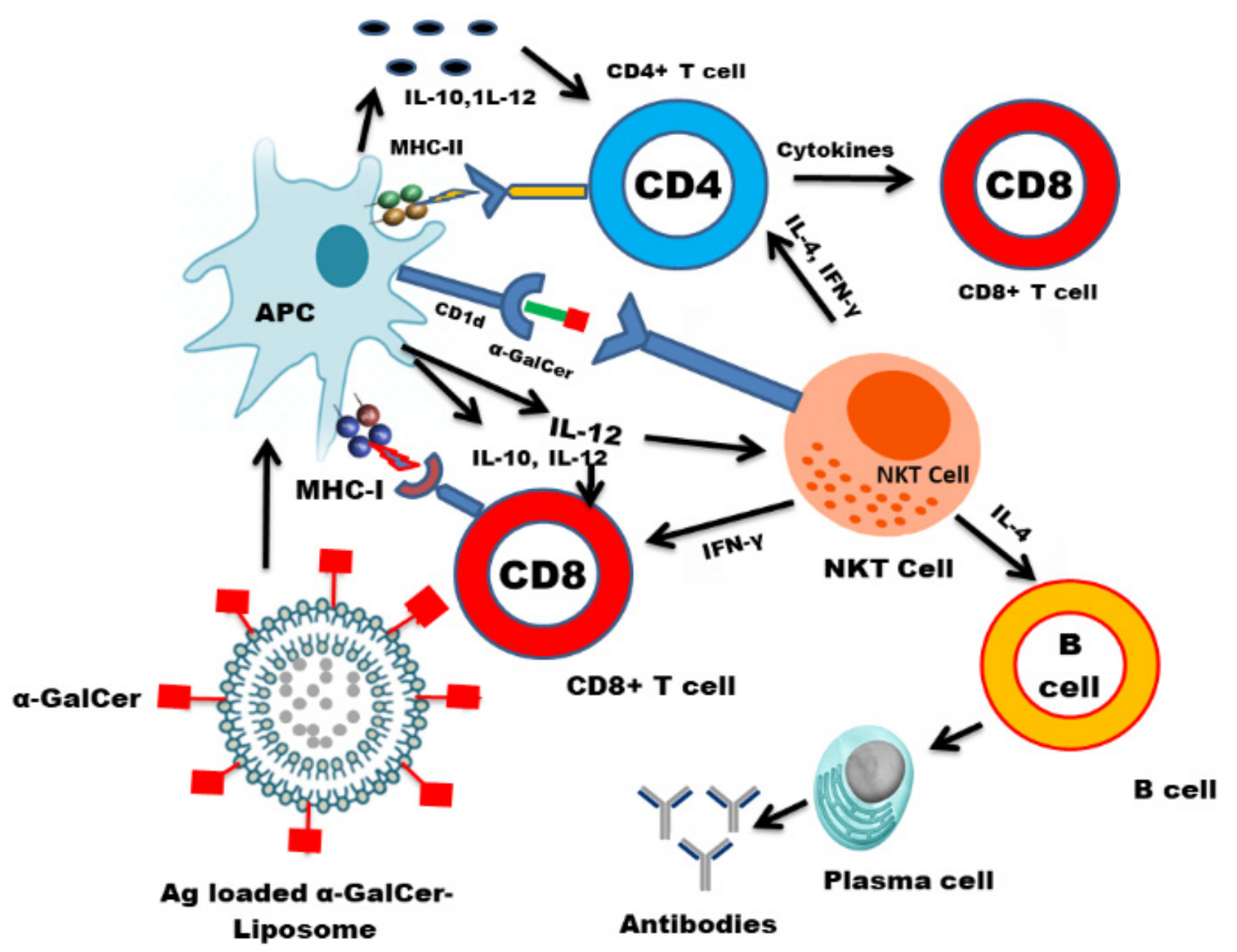

Figure 4. Liposome-incorporated $\alpha$-GalCer and antigens are preferentially taken up and presented by dendritic cells. Liposomes deliver the encapsulated molecules to the cytoplasm and intracellular compartments of the APC for the processing of antigens. It results in the activation of $\mathrm{CD}^{+} \mathrm{T}$ cells, $\mathrm{CD} 4^{+} \mathrm{T}$ cells and NKT cells. NKT cells secrete both Th1 and Th2 cytokines that induce the proliferation of the cell-mediated and humoral immune responses. 


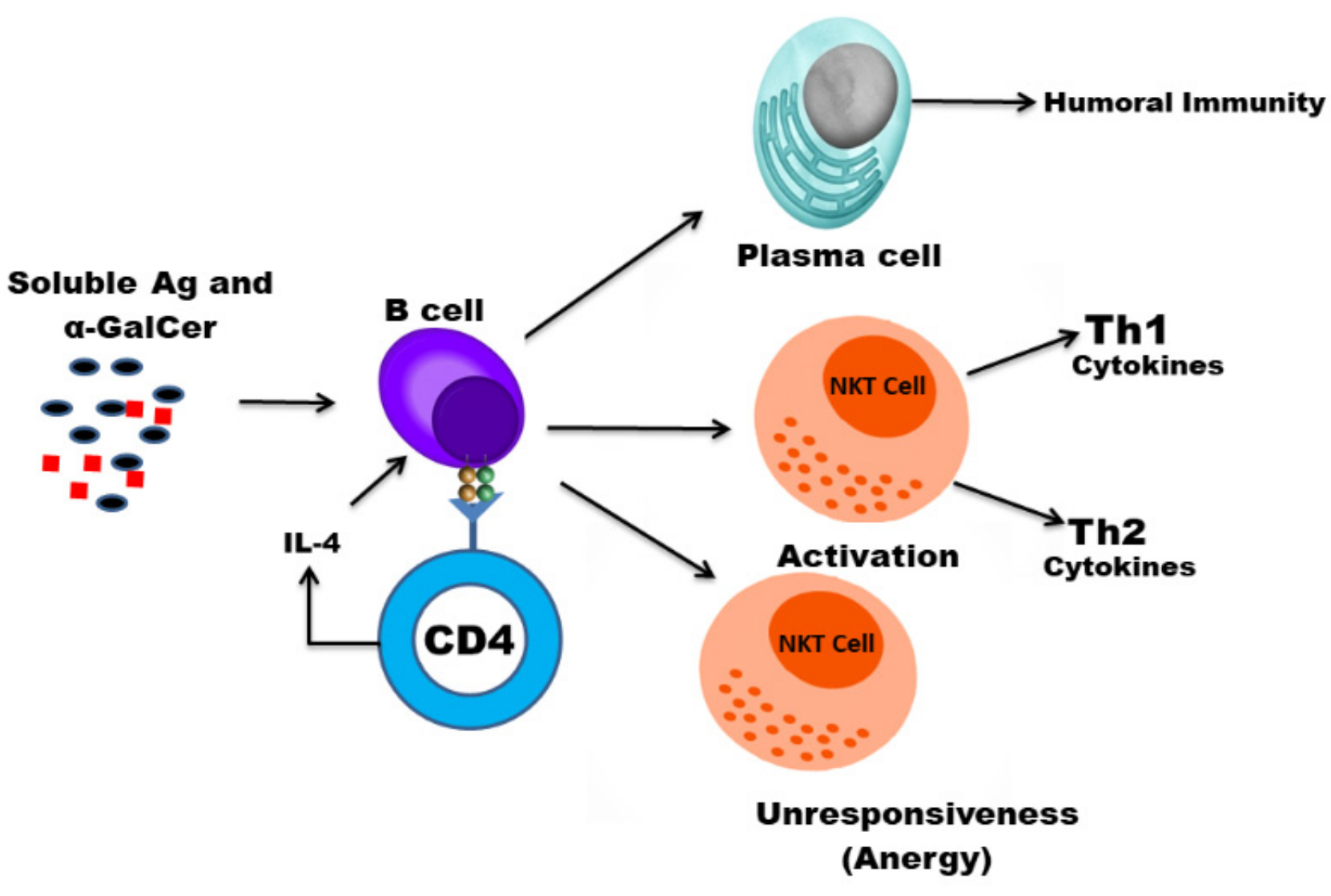

Figure 5. Soluble $\alpha$-GalCer presented by B cells anergize NKT cells. In contrast to dendritic cells, $\alpha$-GalCer-pulsed B cells express low levels of costimulatory molecules and anergize NKT cells.

In contrast to DCs, B cells express lower levels of costimulatory molecules and contribute to NKT cell anergy [106]. Interestingly, liposome-incorporated- $\alpha$-GalCer is preferentially taken up by the dendritic cells and activates iNKT cells without inducing anergy [107]. Thapa et al. demonstrated that the soluble $\alpha$-GalCer is presented by B cells, whereas the nanoparticle-incorporated $\alpha-G a l C e r$ is preferentially presented by DCs. Moreover, glycosphingolipids (GSLs), isolated from S. paucimobilis, specifically activated the iNKT cells in a CD1d-dependent manner [17]. Liposomes composed of GSLs elicited a strong antigen-specific immune response [108]. Moreover, they induced the activation of DCs and increased the production of IFN- $\gamma$ by the splenocytes $[108,109]$. It suggested that the incorporation of iNKT-specific ligands in nanoparticles or liposomes may further potentiate the immunogenicity of encapsulated antigens by enhancing the generation of antigen-specific $\mathrm{CD}^{+} \mathrm{T}$ cells and $\mathrm{CD} 4{ }^{+} \mathrm{T}$ cells that contribute to the development of an effective vaccine against viruses.

\section{Conclusions}

In spite of constituting a very small population of T cells, NKT cells play a very critical role in protecting against viruses. They have both the direct and indirect antiviral effect through the secretion of important cytokines. Contrarily, viruses evade the functioning of the NKT cells by utilizing multiple immune evasion mechanisms. While the NKT-cell ligands have been extensively studied as a potential therapeutic agent in the treatment of cancer, their role, however, as immunoadjuvants has not been widely explored. Some studies showed that NKT-cell ligands have immunoadjuvant potential in eliciting the antigen-specific cell-mediated and humoral immune responses. Nevertheless, their frequent systemic administration results in NKT cell anergy. Nanoparticle-based vaccine formulations have shown their efficacy in the generation of $\mathrm{CD}^{+}$and $\mathrm{CD} 8^{+} \mathrm{T}$ cell responses, the latter is critical to control intracellular infections, particularly viral infections. 
The codelivery of NKT cell ligand and antigens by nanoparticles is suggested to be a very important strategy to prepare an antiviral vaccine because it will not only activate CD4 ${ }^{+}$ and $\mathrm{CD}^{+} \mathrm{T}$ cells, but also stimulate iNKT cells that further contribute in the activation of the cell-mediated and humoral immune responses through the secretion of various cytokines. Moreover, iNKT cell ligand incorporated into nanoparticles can persistently activate iNKT cells without inducing anergy. Thus the codelivery of nanoparticle-incorporated iNKT cell ligand and antigens may be considered an important prophylactic approach to mount a strong antigen-specific antiviral immune response.

Author Contributions: Conceptualization, writing, review and editing, M.A.K.; Review and editing A.K. All authors have read and agreed to the published version of the manuscript.

Funding: This research received no external funding.

Institutional Review Board Statement: Not applicable.

Informed Consent Statement: Not applicable.

Data Availability Statement: Not applicable.

Acknowledgments: The authors would like to thank the Deanship of Scientific Research, Qassim University for the Grant \# 5575-cams1-2019-2-2-I to Masood A. Khan.

Conflicts of Interest: There is no conflict of interest to declare.

\section{References}

1. Bendelac, A.; Savage, P.B.; Teyton, L. The Biology of NKT Cells. Annu. Rev. Immunol. 2007, 25, 297-336. [CrossRef] [PubMed]

2. Godfrey, D.I.; Stankovic, S.; Baxter, A. Raising the NKT cell family. Nat. Immunol. 2010, 11, 197-206. [CrossRef] [PubMed]

3. Berzins, S.P.; Smyth, M.; Baxter, A. Presumed guilty: Natural killer T cell defects and human disease. Nat. Rev. Immunol. 2011, 11, 131-142. [CrossRef] [PubMed]

4. Peralbo, E.; Alonso, C.; Solana, R. Invariant NKT and NKT-like lymphocytes: Two different T cell subsets that are differentially affected by ageing. Exp. Gerontol. 2007, 42, 703-708. [CrossRef] [PubMed]

5. Terrazzano, G.; Bruzzaniti, S.; Rubino, V.; Santopaolo, M.; Palatucci, A.T.; Giovazzino, A.; La Rocca, C.; de Candia, P.; Puca, A.; Perna, F.; et al. T1D progression is associated with loss of CD3+CD56+ regulatory T cells that control CD8+ T cell effector functions. Nat. Metab. 2020, 2, 142-152. [CrossRef] [PubMed]

6. Uldrich, A.; Patel, O.; Cameron, G.; Pellicci, D.; Day, E.B.; Sullivan, L.; Kyparissoudis, K.; Kjer-Nielsen, L.; Vivian, J.; Cao, B.; et al. A semi-invariant $\mathrm{V} \alpha 10+\mathrm{T}$ cell antigen receptor defines a population of natural killer $\mathrm{T}$ cells with distinct glycolipid antigen-Recognition properties. Nat. Immunol. 2011, 12, 616-623. [CrossRef]

7. Reantragoon, R.; Corbett, A.; Sakala, I.G.; Gherardin, N.; Furness, J.B.; Chen, Z.; Eckle, S.; Uldrich, A.; Birkinshaw, R.; Patel, O.; et al. Antigen-loaded MR1 tetramers define T cell receptor heterogeneity in mucosal-associated invariant T cells. J. Exp. Med. 2013, 210, 2305-2320. [CrossRef]

8. Tang, X.-Z.; Jo, J.; Tan, A.T.; Sandalova, E.; Chia, A.; Tan, K.C.; Lee, K.H.; Gehring, A.; De Libero, G.; Bertoletti, A. IL-7 Licenses Activation of Human Liver Intrasinusoidal Mucosal-Associated Invariant T Cells. J. Immunol. 2013, 190, 3142-3152. [CrossRef]

9. Loh, L.; Wang, Z.; Sant, S.; Koutsakos, M.; Jegaskanda, S.; Corbett, A.J.; Liu, L.; Fairlie, D.; Crowe, J.; Rossjohn, J.; et al. Human mucosal-associated invariant $\mathrm{T}$ cells contribute to antiviral influenza immunity via IL-18-dependent activation. Proc. Natl. Acad. Sci. USA 2016, 113, 10133-10138. [CrossRef] [PubMed]

10. Le Bourhis, L.; Martin, E.; Péguillet, I.; Guihot, A.; Froux, N.; Coré, M.; Lévy, E.; Dusseaux, M.; Meyssonnier, V.; Premel, V.; et al. Antimicrobial activity of mucosal-associated invariant T cells. Nat. Immunol. 2010, 11, 701-708. [CrossRef]

11. Salio, M.; Silk, J.D.; Jones, Y.; Cerundolo, V. Biology of CD1- and MR1-Restricted T Cells. Annu. Rev. Immunol. 2014, 32, 323-366. [CrossRef] [PubMed]

12. Gold, M.C.; Cerri, S.; Smyk-Pearson, S.; Cansler, M.E.; Vogt, T.M.; Delepine, J.; Winata, E.; Swarbrick, G.M.; Chua, W.-J.; Yu, Y.Y.L.; et al. Human Mucosal Associated Invariant T Cells Detect Bacterially Infected Cells. PLoS Biol. 2010, 8, e1000407. [CrossRef] [PubMed]

13. Lepore, M.; Kalinichenko, A.; Colone, A.; Paleja, B.; Singhal, A.; Tschumi, A.; Lee, B.; Poidinger, M.; Zolezzi, F.; Quagliata, L.; et al. Parallel T-cell cloning and deep sequencing of human MAIT cells reveal stable oligoclonal TCR $\beta$ repertoire. Nat. Commun. 2014, 5, 3866. [CrossRef]

14. Morita, M.; Motoki, K.; Akimoto, K.; Natori, T.; Sakai, T.; Sawa, E.; Yamaji, K.; Koezuka, Y.; Kobayashi, E.; Fukushima, H. Structure-Activity relationship of $\alpha$-Galactosylceramide against B-16 bearing mice. J. Med. Chem. 1995, 38, 2176-2187. [CrossRef] [PubMed] 
15. Brown, L.C.W.; Penaranda, C.; Kashyap, P.C.; Williams, B.B.; Clardy, J.; Kronenberg, M.; Sonnenburg, J.L.; Comstock, L.E.; Bluestone, J.A.; Fischbach, M.A. Production of $\alpha$-Galactosylceramide by a Prominent Member of the Human Gut Microbiota. PLoS Biol. 2013, 11, e1001610. [CrossRef]

16. von Gerichten, J.; Schlosser, K.; Lamprecht, D.; Morace, I.; Eckhardt, M.; Wachten, D.; Jennemann, R.; Gröne, H.-J.; Mack, M.; Sandhoff, R. Diastereomer-specific quantification of bioactive hexosylceramides from bacteria and mammals. J. Lipid Res. 2017, 58, 1247-1258. [CrossRef] [PubMed]

17. Sriram, V.; Du, W.; Gervay-Hague, J.; Brutkiewicz, R.R. Cell wall glycosphingolipids of Sphingomonas paucimobilis are CD1dspecific ligands for NKT cells. Eur. J. Immunol. 2005, 35, 1692-1701. [CrossRef]

18. Brutkiewicz, R.R. CD1d ligands: The good, the bad, and the ugly. J. Immunol. 2006, 177, 769-775. [CrossRef]

19. Albacker, L.A.; Chaudhary, V.; Chang, Y.J.; Kim, H.Y.; Chuang, Y.T.; Pichavant, M.; DeKruyff, R.H.; Savage, P.B.; Umetsu, D.T. Invariant natural killer T cells recognize a fungal glycosphingolipid that can induce airway hyper reactivity. Nat. Med. 2013, 19, 1297-1304. [CrossRef]

20. Dhodapkar, M.V.; Kumar, V. Type II NKT Cells and Their Emerging Role in Health and Disease. J. Immunol. 2017, 198, 1015-1021. [CrossRef]

21. Brutkiewicz, R.R.; Lin, Y.; Cho, S.; Hwang, Y.K.; Sriram, V.; Roberts, T.J. CD1d-mediated antigen presentation to natural killer T (NKT) cells. Crit. Rev. Immunol. 2003, 23, 403-419. [CrossRef] [PubMed]

22. Coquet, J.; Chakravarti, S.; Kyparissoudis, K.; McNab, F.W.; Pitt, L.A.; McKenzie, B.S.; Berzins, S.P.; Smyth, M.; Godfrey, D.I. Diverse cytokine production by NKT cell subsets and identification of an IL-17-producing CD4-NK1.1- NKT cell population. Proc. Natl. Acad. Sci. USA 2008, 105, 11287-11292. [CrossRef] [PubMed]

23. James, E.E.; Andrew, J.K.; Webb, T.J. Raising the roof: The preferential pharmacological stimulation of Th1 and Th2 responses mediated by NKT cells. Med. Res. Rev. 2014, 34, 45-76.

24. Liu, Z.; Guo, J. NKT-Cell glycolipid agonist as adjuvant in synthetic vaccine. Carbohydr. Res. 2017, 452, 78-90. [CrossRef]

25. Kakimi, K.; Guidotti, L.G.; Koezuka, Y.; Chisari, F. Natural Killer T Cell Activation Inhibits Hepatitis B Virus Replication in Vivo. J. Exp. Med. 2000, 192, 921-930. [CrossRef] [PubMed]

26. Liu, J.; Glosson, N.L.; Du, W.; Gervay-Hague, J.; Brutkiewicz, R.R. A Thr/Ser dual residue motif in the cytoplasmic tail of human CD1d is important for the down-regulation of antigen presentation following a herpes simplex virus 1 infection. Immunology 2013, 140, 191-201. [CrossRef]

27. Exley, M.A.; Bigley, N.J.; Cheng, O.; Tahir, S.M.; Smiley, S.T.; Carter, Q.L.; Stills, H.F.; Grusby, M.J.; Koezuka, Y.; Taniguchi, M.; et al. CD1d-Reactive T-cell activation leads to amelioration of disease caused by diabetogenic encephalomyocarditis viruses. $J$. Leukoc. Biol. 2001, 69, 713-718. [PubMed]

28. Diana, J.; Griseri, T.; Lagaye, S.; Beaudoin, L.; Autrusseau, E.; Gautron, A.-S.; Tomkiewicz, C.; Herbelin, A.; Barouki, R.; von Herrath, M.; et al. NKT Cell-Plasmacytoid Dendritic Cell Cooperation via OX40 Controls Viral Infection in a Tissue-Specific Manner. Immunity 2009, 30, 289-299. [CrossRef]

29. Ho, L.; Denney, L.; Luhn, K.; Teoh, D.; Clelland, C.; McMichael, A.J. Activation of invariant NKT cells enhances the innate immune response and improves the disease course in influenza A virus infection. Eur. J. Immunol. 2008, 38, 1913-1922. [CrossRef] [PubMed]

30. van Dommelen, S.L.H.; Tabarias, H.A.; Smyth, M.J.; Degli-Esposti, M.A.; Law, L.M.J.; Everitt, J.C.; Beatch, M.D.; Holmes, C.F.B.; Hobman, T.C. Activation of Natural Killer (NK) T Cells during Murine Cytomegalovirus Infection Enhances the Antiviral Response Mediated by NK Cells. J. Virol. 2003, 77, 1764-1771. [CrossRef]

31. Wu, C.Y.; Feng, Y.; Qian, G.C.; Wu, J.H.; Luo, J.; Wang, Y.; Chen, G.J.; Guo, X.-K.; Wang, Z.J. $\alpha$-Galactosylceramide protects mice from lethal Coxsackievirus B3 infection and subsequent myocarditis. Clin. Exp. Immunol. 2010, 162, 178-187. [CrossRef]

32. Johnson, T.R.; Hong, S.; Van Kaer, L.; Koezuka, Y.; Graham, B.S. NK T Cells Contribute to Expansion of CD8 + T Cells and Amplification of Antiviral Immune Responses to Respiratory Syncytial Virus. J. Virol. 2002, 76, 4294-4303. [CrossRef]

33. De Santo, C.; Salio, M.; Masri, S.H.; Lee, L.Y.-H.; Dong, T.; Speak, A.; Porubsky, S.; Booth, S.; Veerapen, N.; Besra, G.; et al. Invariant NKT cells reduce the immunosuppressive activity of influenza A virus-induced myeloid-derived suppressor cells in mice and humans. J. Clin. Investig. 2008, 118, 4036-4048. [CrossRef]

34. Singh, D.; Ghate, M.; Godbole, S.; Kulkarni, S.; Thakar, M. Functional Invariant Natural Killer T Cells Secreting Cytokines Are Associated with Non-Progressive Human Immunodeficiency Virus-1 Infection but Not With Suppressive Anti-Retroviral Treatment. Front. Immunol. 2018, 9, 1152. [CrossRef] [PubMed]

35. Nichols, K.E.; Hom, J.; Gong, S.; Ganguly, A.; Ma, C.; Cannons, J.L.; Tangye, P.S.; Schwartzberg, P.L.; Koretzky, G.A.; Stein, P.L. Regulation of NKT cell development by SAP, the protein defective in XLP. Nat. Med. 2005, 11, 340-345. [CrossRef]

36. Rigaud, S.; Fondanèche, M.-C.; Lambert, N.C.; Pasquier, B.; Mateo, V.; Soulas-Sprauel, P.; Galicier, L.; Le Deist, F.; Rieux-Laucat, F.; Revy, P.; et al. XIAP deficiency in humans causes an X-linked lymphoproliferative syndrome. Nature 2006, 444, 110-114. [CrossRef] [PubMed]

37. Locci, M.; Draghici, E.; Marangoni, F.; Bosticardo, M.; Catucci, M.; Aiuti, A.; Cancrini, C.; Marodi, L.; Espanol, T.; Bredius, R.G.; et al. The Wiskott-Aldrich syndrome protein is required for iNKT cell maturation and function. J. Exp. Med. 2009, 206, 735-742. [CrossRef] [PubMed] 
38. Levy, O.; Orange, J.S.; Hibberd, P.; Steinberg, S.; LaRussa, P.; Weinberg, A.; Wilson, S.B.; Shaulov, A.; Fleisher, G.; Geha, R.S.; et al. Disseminated varicella infection due to the vaccine strain of varicella-zoster virus, in a patient with a novel deficiency in natural killer T cells. J. Infect. Dis. 2003, 188, 948-953. [CrossRef] [PubMed]

39. Grubor-Bauk, B.; Simmons, A.; Mayrhofer, G.; Speck, P.G. Impaired clearance of herpes simplex virus type 1 from mice lacking CD1d or NKT cells expressing the semivariant V alpha 14-J alpha 281 TCR. J. Immunol. 2003, 170, 1430-1434. [CrossRef]

40. Yuan, W.; Dasgupta, A.; Cresswell, P. Herpes simplex virus evades naturalkiller T cell recognition by suppressing CD1d recycling. Nat. Immunol. 2006, 7, 835-842. [CrossRef]

41. Tyznik, A.J.; Tupin, E.; Nagarajan, N.A.; Her, M.J.; Benedict, C.A.; Kronenberg, M. Cutting edge: The mechanism of invariant NKT cell responses to viral danger signals. J. Immunol. 2008, 181, 4452-4456. [CrossRef]

42. Broxmeyer, H.E.; Dent, A.; Cooper, S.; Hangoc, G.; Wang, Z.-Y.; Du, W.; Gervay-Haque, J.; Sriram, V.; Renukaradhya, G.J.; Brutkiewicz, R.R. A role for natural killer T cells and CD1d molecules in counteracting suppression of hematopoiesis in mice induced by infection with murine cytomegalovirus. Exp. Hematol. 2007, 35, 87-93. [CrossRef]

43. Paget, C.; Ivanov, S.; Fontaine, J.; Blanc, F.; Pichavant, M.; Renneson, J.; Bialecki, E.; Pothlichet, J.; Vendeville, C.; Barba-Speath, G.; et al. Potential Role of Invariant NKT Cells in the Control of Pulmonary Inflammation and CD8+ T Cell Response during Acute Influenza A Virus H3N2 Pneumonia. J. Immunol. 2011, 186, 5590-5602. [CrossRef] [PubMed]

44. Ajuebor, M.N. Role of NKT cells in the digestive system. I. Invariant NKT cells and liver diseases: Is there strength in numbers? Am. J. Physiol. Gastrointest. Liver Physiol. 2007, 293, G651-G656. [CrossRef] [PubMed]

45. Wang, X.F.; Lei, Y.; Chen, M.; Chen, C.B.; Ren, H.; Shi, T.D. PD-1/PDL1 and CD28/CD80 pathways modulate naturalkiller T cell function to inhibit hepatitis B virus replication. J. Viral. Hepat. 2013, 20, 27-39. [CrossRef] [PubMed]

46. Zeissig, S.; Murata, K.; Sweet, L.; Publicover, J.; Hu, Z.; Kaser, A.; Bosse, E.; Iqbal, J.; Hussain, M.M.; Balschun, K.; et al. Hepatitis B virus-induced lipid alterations contribute to naturalkiller T cell-dependent protective immunity. Nat. Med. 2012, 18, 1060-1068. [CrossRef]

47. Villanueva, A.I.; Haeryfar, S.M.; Mallard, B.A.; Kulkarni, R.R.; Sharif, S. Functions of NKT cells are modulated by TLR ligands and IFN $\alpha$. Innate Immun. 2015, 21, 275-288. [CrossRef] [PubMed]

48. Bowie, A.G.; Haga, I.R. The role of Toll-like receptors in the host response to viruses. Mol. Immunol. 2005, 42, 859-867. [CrossRef] [PubMed]

49. Schäfer, A.; Hühr, J.; Schwaiger, T.; Dorhoi, A.; Mettenleiter, T.C.; Blome, S.; Schröder, C.; Blohm, U. Porcine Invariant Natural Killer T Cells: Functional Profiling and Dynamics in Steady State and Viral Infections. Front. Immunol. 2019, 10, 1380. [CrossRef] [PubMed]

50. Renukaradhya, G.J.; Manickam, C.; Khatri, M.; Rauf, A.; Li, X.; Tsuji, M.; Rajashekara, G.; Dwivedi, V. Functional invariant NKT cells in pig lungs regulate the airway hyperreactivity: A potential animal model. J. Clin. Immunol. 2010, 31, 228-239. [CrossRef] [PubMed]

51. Artiaga, B.L.; Yang, G.; Hutchinson, T.E.; Loeb, J.C.; Richt, J.A.; Lednicky, J.A.; Salek-Ardakani, S.; Driver, J.P. Rapid control of pandemic H1N1 influenza by targeting NKT-cells. Sci. Rep. 2016, 6, 37999. [CrossRef] [PubMed]

52. Dwivedi, V.; Manickam, C.; Dhakal, S.; Binjawadagi, B.; Ouyang, K.; Hiremath, J.; Khatri, M.; Hague, J.G.; Lee, C.W.; Renukaradhya, G.J. Adjuvant effects of invariant NKT cell ligand potentiates the innate and adaptive immunity to an inactivated H1N1 swine influenza virus vaccine in pigs. Veter Microbiol. 2016, 186, 157-163. [CrossRef] [PubMed]

53. Pegu, A.; Asokan, M.; Wu, L.; Wang, K.; Hataye, J.; Casazza, J.P.; Guo, X.; Shi, W.; Georgiev, I.; Zhou, T.; et al. Activation and lysis of human CD4 cells latently infected with HIV-1. Nat. Commun. 2015, 6, 8447. [CrossRef]

54. Courtney, A.N.; Nehete, P.; Nehete, B.P.; Thapa, P.; Zhou, D.; Sastry, K.J. Alpha-galactosylceramide is an effective mucosal adjuvant for repeated intranasal or oral delivery of HIV peptide antigens. Vaccine 2009, 27, 3335-3341. [CrossRef]

55. Sandberg, J.K.; Fast, N.M.; Palacios, E.H.; Fennelly, G.; Dobroszycki, J.; Palumbo, P.; Wiznia, A.; Grant, R.M.; Bhardwaj, N.; Rosenberg, M.G.; et al. Selective loss of innate $\mathrm{CD}^{+} \mathrm{V}$ alpha 24 natural killer $\mathrm{T}$ cells in human immunodeficiency virus infection. J. Virol. 2002, 76, 7528-7534. [CrossRef]

56. Moll, M.; Kuylenstierna, C.; Gonzalez, V.D.; Andersson, S.K.; Bosnjak, L.; Sönnerborg, A.; Quigley, M.F.; Sandberg, J.K. Severe functional impairment and elevated PD-1 expression in CD1d-restricted NKT cells retained during chronic HIV-1 infection. Eur. J. Immunol. 2009, 39, 902-911. [CrossRef] [PubMed]

57. Cho, S.; Knox, K.S.; Kohli, L.M.; He, J.J.; Exley, M.A.; Wilson, S.B.; Brutkiewicz, R.R. Impaired cell surface expression of human CD1d by the formation of an HIV-1 Nef/CD1d complex. Virology 2005, 337, 242-252. [CrossRef]

58. Chen, N.; McCarthy, C.; Drakesmith, H.; Li, D.; Cerundolo, V.; McMichael, A.J.; Screaton, G.R.; Xu, X.-N. HIV-1 down-regulates the expression of CD1d via Nef. Eur. J. Immunol. 2006, 36, 278-286. [CrossRef] [PubMed]

59. Motsinger-Reif, A.; Haas, D.W.; Stanic-Kostic, A.; Van Kaer, L.; Joyce, S.; Unutmaz, D. CD1d-restricted Human Natural Killer T Cells Are Highly Susceptible to Human Immunodeficiency Virus 1 Infection. J. Exp. Med. 2002, 195, 869-879. [CrossRef]

60. Fernandez, C.S.; Kelleher, A.D.; Finlayson, R.; Godfrey, D.I.; Kent, S.J. NKT cell depletion in humans during early HIV infection. Immunol. Cell Biol. 2014, 92, 578-590. [CrossRef]

61. Mureithi, M.W.; Cohen, K.; Moodley, R.; Poole, D.; Mncube, Z.; Kasmar, A.; Moody, D.B.; Goulder, P.J.; Walker, B.D.; Altfeld, M.; et al. Impairment of CD1d-Restricted Natural Killer T Cells in Chronic HIV Type 1 Clade C Infection. AIDS Res. Hum. Retroviruses 2011, 27, 501-509. [CrossRef]

62. Brutkiewicz, R.R. Cell Signaling Pathways That Regulate Antigen Presentation. J. Immunol. 2016, 197, 2971-2979. [CrossRef] 
63. Renukaradhya, G.J.; Webb, T.; Khan, M.A.; Lin, Y.L.; Du, W.; Gervay-Hague, J.; Brutkiewicz, R. Virus-Induced Inhibition of CD1d1-Mediated Antigen Presentation: Reciprocal Regulation by p38 and ERK. J. Immunol. 2005, 175, 4301-4308. [CrossRef]

64. Liu, J.; Gallo, R.M.; Khan, M.A.; Iyer, A.K.; Kratzke, I.M.; Brutkiewicz, R.R. JNK2 modulates the CD1d-Dependent and -Independent activation of iNKT cells. Eur. J. Immunol. 2018, 49, 255-265. [CrossRef]

65. Iyer, A.K.; Liu, J.; Gallo, R.M.; Kaplan, M.H.; Brutkiewicz, R.R. STAT3 promotes CD1d-mediated lipid antigen presentation by regulating a critical gene in glycosphingolipid biosynthesis. Immunology 2015, 146, 444-455. [CrossRef]

66. He, Y.; Fisher, R.; Chowdhury, S.; Sultana, I.; Pereira, C.P.; Bray, M.; Reed, J.L. Vaccinia Virus Induces Rapid Necrosis in Keratinocytes by a STAT3-Dependent Mechanism. PLoS ONE 2014, 9, e113690. [CrossRef]

67. Renukaradhya, G.J.; Khan, M.A.; Shaji, D.; Brutkiewicz, R. Vesicular Stomatitis Virus Matrix Protein Impairs CD1d-Mediated Antigen Presentation through Activation of the p38 MAPK Pathway. J. Virol. 2008, 82, 12535-12542. [CrossRef] [PubMed]

68. Lin, Y.; Roberts, T.J.; Wang, C.; Cho, S.; Brutkiewicz, R. Long-term loss of canonical NKT cells following an acute virus infection. Eur. J. Immunol. 2005, 35, 879-889. [CrossRef] [PubMed]

69. Hobbs, J.A.; Cho, S.; Roberts, T.J.; Sriram, V.; Zhang, J.; Xu, M.; Brutkiewicz, R.R. Selective Loss of Natural Killer T Cells by Apoptosis following Infection with Lymphocytic Choriomeningitis Virus. J. Virol. 2001, 75, 10746-10754. [CrossRef] [PubMed]

70. Kovats, S.; Turner, S.; Simmons, A.; Powe, T.; Chakravarty, E.; Alberola-Ila, J. West Nile virus-Infected human dendritic cells fail to fully activate invariant natural killer T cells. Clin. Exp. Immunol. 2016, 186, 214-226. [CrossRef] [PubMed]

71. Rao, V.; Pham, H.T.; Kulkarni, A.; Yang, Y.; Liu, X.; Knipe, D.M.; Cresswell, P.; Yuan, W. Herpes Simplex Virus 1 Glycoprotein B and US3 Collaborate To Inhibit CD1d Antigen Presentation and NKT Cell Function. J. Virol. 2011, 85, 8093-8104. [CrossRef]

72. Keir, M.E.; Butte, M.; Freeman, G.J.; Sharpe, A.H. PD-1 and Its Ligands in Tolerance and Immunity. Annu. Rev. Immunol. 2008, 26, 677-704. [CrossRef] [PubMed]

73. Parekh, V.V.; Lalani, S.; Kim, S.; Halder, R.; Azuma, M.; Yagita, H.; Kumar, V.; Wu, L.; Van Kaer, L. PD-1/PD-L Blockade Prevents Anergy Induction and Enhances the Anti-Tumor Activities of Glycolipid-Activated Invariant NKT Cells. J. Immunol. 2009, 182, 2816-2826. [CrossRef] [PubMed]

74. Day, C.L.; Kaufmann, D.E.; Kiepiela, P.; Brown, J.A.; Moodley, E.S.; Reddy, S.; Mackey, E.W.; Miller, J.D.; Leslie, A.; DePierres, C.; et al. PD-1 expression on HIV-specific T cells is associated with T-cell exhaustion and disease progression. Nature 2006, 443, 350-354. [CrossRef] [PubMed]

75. Zingaropoli, M.A.; Perri, V.; Pasculli, P.; Dezza, F.C.; Nijhawan, P.; Savelloni, G.; La Torre, G.; D’Agostino, C.; Mengoni, F.; Lichtner, M.; et al. Major reduction of NKT cells in patients with severe COVID-19 pneumonia. Clin. Immunol. 2020, 222, 108630. [CrossRef] [PubMed]

76. Fifis, T.; Gamvrellis, A.; Crimeen-Irwin, B.; Pietersz, G.A.; Li, J.; Mottram, P.L.; McKenzie, I.F.C.; Plebanski, M. Size-Dependent Immunogenicity: Therapeutic and Protective Properties of Nano-Vaccines against Tumors. J. Immunol. 2004, 173, 3148-3154. [CrossRef]

77. Syed, F.M.; Khan, M.A.; Nasti, T.H.; Ahmad, N.; Mohammad, O. Antigen entrapped in escheriosomes leads to the generation of CD4+ helper and CD8+ cytotoxic T cell response. Vaccine 2003, 21, 2383-2393. [CrossRef]

78. Ahmad, N.; Khan, M.A.; Owais, M. Fusogenic potential of prokaryotic membrane lipids: Implication in vaccine development. Eur. J. Biochem. 2001, 268, 1-10. [CrossRef]

79. Kumari, S.; Chatterjee, K. Biomaterials-based formulations and surfaces to combat viral infectious diseases. APL Bioeng. 2021, 5, 011503. [CrossRef]

80. Tao, W.; Gill, H.S. M2e-immobilized gold nanoparticles as influenza A vaccine: Role of soluble M2e and longevity of protection. Vaccine 2015, 33, 2307-2315. [CrossRef]

81. Guo, H.-C.; Feng, X.-M.; Sun, S.-Q.; Wei, Y.-Q.; Sun, D.-H.; Liu, X.-T.; Liu, Z.-X.; Luo, J.-X.; Yin, H. Immunization of mice by Hollow Mesoporous Silica Nanoparticles as carriers of Porcine Circovirus Type 2 ORF2 Protein. Virol. J. 2012, 9, 108. [CrossRef]

82. Pantarotto, D.; Partidos, C.D.; Hoebeke, J.; Brown, F.; Kramer, E.; Briand, J.P.; Muller, S.; Prato, M.; Bianco, A. Immunization with peptide-functionalized carbon nanotubes enhances virus-specific neutralizing antibody responses. Chem. Biol. 2003, $10,61-66$. [CrossRef]

83. Khan, M.A.; Ahmad, N.; Moin, S.; Mannan, A.; Wajahul, H.; Pasha, S.T.; Khan, A.; Owais, M. Tuftsin-mediated immunoprophylaxis against an isolate of Aspergillus fumigatus shows less in vivo susceptibility to amphotericin B. FEMS Immunol. Med. Microbiol. 2005, 44, 269-276. [CrossRef] [PubMed]

84. Khan, A.A.; Allemailem, K.S.; Almatroodi, S.A.; Almatroudi, A.; Rahmani, A.H. Recent strategies towards the surface modification of liposomes: An innovative approach for different clinical applications. 3 Biotech 2020, 10, 1-15. [CrossRef] [PubMed]

85. Brunel, F.; Darbouret, A.; Ronco, J. Cationic lipid DC-Chol induces an improved and balanced immunity able to overcome the unresponsiveness to the hepatitis B vaccine. Vaccine 1999, 17, 2192-2203. [CrossRef]

86. Joseph, A.; Itskovitz-Cooper, N.; Samira, S.; Flasterstein, O.; Eliyahu, H.; Simberg, D.; Goldwaser, I.; Barenholz, Y.; Kedar, E. A new intranasal influenza vaccine based on a novel polycationic lipid-Ceramide carbamoyl-spermine (CCS): I. Immunogenicity and efficacy studies in mice. Vaccine 2006, 24, 3990-4006. [CrossRef] [PubMed]

87. Blom, R.A.M.; Erni, S.T.; Krempaská, K.; Schaerer, O.; Van Dijk, R.M.; Amacker, M.; Moser, C.; Hall, S.R.R.; Von Garnier, C.; Blank, F. A Triple Co-Culture Model of the Human Respiratory Tract to Study Immune-Modulatory Effects of Liposomes and Virosomes. PLoS ONE 2016, 11, e0163539. [CrossRef] 
88. Jin, Z.; Gao, S.; Cui, X.; Sun, D.; Zhao, K. Adjuvants and delivery systems based on polymeric nanoparticles for mucosal vaccines. Int. J. Pharm. 2019, 572, 118731. [CrossRef]

89. Mehrabi, M.; Montazeri, H.; Dounighi, N.M.; Rashti, A.; Vakili-Ghartavol, R. Chitosan-Based Nanoparticles in Mucosal Vaccine Delivery. Arch. Razi Inst. 2018, 73, 165-176.

90. Liu, Q.; Zheng, X.; Zhang, C.; Shao, X.; Zhang, X.; Zhang, Q.; Jiang, X. Conjugating influenza a (H1N1) antigen to ntrimethylaminoethylmethacrylate chitosan nanoparticles improve the immunogenicity of the antigen after nasal administration. J. Med. Virol. 2015, 87, 1807-1815. [CrossRef]

91. Gu, P.; Wusiman, A.; Zhang, Y.; Liu, Z.; Bo, R.; Hu, Y.; Liu, J.; Wang, D. Rational Design of PLGA Nanoparticle Vaccine Delivery Systems to Improve Immune Responses. Mol. Pharm. 2019, 16, 5000-5012. [CrossRef]

92. Dhakal, S.; Hiremath, J.; Bondra, K.; Lakshmanappa, Y.S.; Shyu, D.-L.; Ouyang, K.; Kang, K.-I.; Binjawadagi, B.; Goodman, J.; Tabynov, K.; et al. Biodegradable nanoparticle delivery of inactivated swine influenza virus vaccine provides heterologous cell-mediated immune response in pigs. J. Control. Release 2017, 247, 194-205. [CrossRef]

93. Akondy, R.S.; Monson, N.D.; Miller, J.D.; Edupuganti, S.; Teuwen, D.; Wu, H.; Quyyumi, F.; Garg, S.; Altman, J.D.; Del Rio, C.; et al. The Yellow Fever Virus Vaccine Induces a Broad and Polyfunctional Human Memory CD8+ T Cell Response. J. Immunol. 2009, 183, 7919-7930. [CrossRef]

94. Sei, J.J.; Cox, K.S.; Dubey, S.A.; Antonello, J.M.; Krah, D.L.; Casimiro, D.R.; Vora, K.A. Effector and Central Memory PolyFunctional CD4+ and CD8+ T Cells are Boosted upon ZOSTAVAX®Vaccination. Front. Immunol. 2015, 6, 553. [CrossRef]

95. Kulkarni, R.R.; Haeryfar, S.M.; Sharif, S. The invariant NKT cell subset in anti-viral defenses: A dark horse in anti-influenza immunity? J. Leukoc. Biol. 2010, 88, 635-643. [CrossRef]

96. Kok, W.L.; Denney, L.; Benam, K.; Cole, S.; Clelland, C.; McMichael, A.J.; Ho, L.-P. Pivotal Advance: Invariant NKT cells reduce accumulation of inflammatory monocytes in the lungs and decrease immune-pathology during severe influenza A virus infection. J. Leukoc. Biol. USA 2011, 91, 357-368. [CrossRef]

97. Fujii, S.-I.; Shimizu, K.; Hemmi, H.; Fukui, M.; Bonito, A.J.; Chen, G.; Franck, R.W.; Tsuji, M.; Steinman, R.M. Glycolipid alpha-C-galactosylceramide is a distinct inducer of dendritic cell function during innate and adaptive immune responses of mice. Proc. Natl. Acad. Sci. USA 2006, 103, 11252-11257. [CrossRef] [PubMed]

98. Galli, G.; Nuti, S.; Tavarini, S.; Galli-Stampino, L.; De Lalla, C.; Casorati, G.; Dellabona, P.; Abrignani, S. CD1d-restricted Help to B Cells By Human Invariant Natural Killer T Lymphocytes. J. Exp. Med. 2003, 197, 1051-1057. [CrossRef] [PubMed]

99. Artiaga, B.L.; Yang, G.; Hackmann, T.J.; Liu, Q.; Richt, J.A.; Salek-Ardakani, S.; Castleman, W.L.; Lednicky, J.A.; Driver, J.P. $\alpha$-Galactosylceramide protects swine against influenza infection when administered as a vaccine adjuvant. Sci. Rep. 2016, 6, 23593. [CrossRef] [PubMed]

100. Driver, J.P.; Madrid, D.M.D.C.; Gu, W.; Artiaga, B.L.; Richt, J.A. Modulation of Immune Responses to Influenza A Virus Vaccines by Natural Killer T Cells. Front. Immunol. 2020, 11, 2172. [CrossRef] [PubMed]

101. Tefit, J.N.; Crabé, S.; Orlandini, B.; Nell, H.; Bendelac, A.; Deng, S.; Savage, P.B.; Teyton, L.; Serra, V. Efficacy of ABX196, a new NKT agonist, in prophylactic human vaccination. Vaccine 2014, 32, 6138-6145. [CrossRef] [PubMed]

102. Huang, Y.; Chen, A.; Li, X.; Chen, Z.; Zhang, W.; Song, Y.; Gurner, D.; Gardiner, D.; Basu, S.; Ho, D.D.; et al. Enhancement of HIV DNA vaccine immunogenicity by the NKT cell ligand, $\alpha$-galactosylceramide. Vaccine 2008, 26, 1807-1816. [CrossRef]

103. Fujii, S.-I.; Shimizu, K.; Smith, C.L.; Bonifaz, L.; Steinman, R.M. Activation of Natural Killer T Cells by $\alpha$-Galactosylceramide Rapidly Induces the Full Maturation of Dendritic Cells In Vivo and Thereby Acts as an Adjuvant for Combined CD4 and CD8 T Cell Immunity to a Coadministered Protein. J. Exp. Med. 2003, 198, 267-279. [CrossRef] [PubMed]

104. Neumann, S.; Young, K.; Compton, B.; Anderson, R.; Painter, G.; Hook, S. Synthetic TRP2 long-peptide and $\alpha$-galactosylceramide formulated into cationic liposomes elicit CD8 + T-cell responses and prevent tumour progression. Vaccine 2015, 33, 5838-5844. [CrossRef] [PubMed]

105. Dolen, Y.; Kreutz, M.; Gileadi, U.; Tel, J.; Vasaturo, A.; Van Dinther, E.A.W.; Van Hout-Kuijer, M.A.; Cerundolo, V.; Figdor, C.G. Co-delivery of PLGA encapsulated invariant NKT cell agonist with antigenic protein induce strong T cell-mediated antitumor immune responses. OncoImmunology 2015, 5, e1068493. [CrossRef]

106. Singh, A.K.; Gaur, P.; Das, S.N. Natural killer T cell anergy, co-stimulatory molecules and immunotherapeutic interventions. Hum. Immunol. 2014, 75, 250-260. [CrossRef]

107. Thapa, P.; Zhang, G.; Xia, C.; Gelbard, A.; Overwijk, W.W.; Liu, C.; Hwu, P.; Chang, D.Z.; Courtney, A.; Sastry, J.K.; et al. Nanoparticle formulated alpha-galactosylceramide activates NKT cells without inducing anergy. Vaccine 2009, 27, 3484-3488. [CrossRef] [PubMed]

108. Inoue, J.; Ideue, R.; Takahashi, D.; Kubota, M.; Kumazawa, Y. Liposomal glycosphingolipids activate natural killer T cell-mediated immune responses through the endosomal pathway. J. Control. Release 2009, 133, 18-23. [CrossRef]

109. Khan, M.A.; Aljarbou, A.N.; Aldebasi, Y.H.; Alorainy, M.S.; Rahmani, A.H.; Younus, H.; Khan, A. Liposomal formulation of glycosphingolipids from Sphingomonas paucimobilis induces antitumor immunity in mice. J. Drug Target. 2018, 26, 709-719. [CrossRef] 